\title{
Effect of 1-Methylcyclopropene Treatment on Ripening and Quality of European Plum (Prunus domestica L.)
}

\author{
Abdel-Moety Salama*, Michael Neumüller ${ }^{* *}$ and Dieter \\ Treutter* \\ *Horticulture Deptartment, Faculty of A griculture, Kafr El-Sheikh \\ University, 33516-Egypt, ${ }^{* *}$ Bayerisches Obstzentrum, Am Süßbach, \\ 85399 Hallbergmoos and ${ }^{* * *}$ Associate Professorship of Fruit \\ Science, Technische Universität München, D-85354, Freising - \\ Weihenstephan, Germany.
}

\begin{abstract}
THYLENE action inhibition by 1-methylcyclopropene (1-MCP) Cextends postharvest life of many climacteric fruits. This work evaluates the effect of $1-\mathrm{MCP}(0.625 \mathrm{ppm})$ treatment on the phy siological behavior and quality during postharvest life of 'Katinka' and 'Haganta' European plum (Prunus domestica L.) in 2012 and 2013. 1-MCP treatment of the fruits reduced ethylene production more than $30 \%$ and delay ed the climacteric peak in 'Haganta' and 'Katinka'. In addition, 1-MCP obviously reduced respiration rate for 'Katinka'. 1-MCP delayed fruit ripening, as shown by lower soluble solids content (SSC) in treated fruits at the beginning of storage and by a significant higher SSC at the end of storage. Moreover, it significantly decreased weight loss and delay ed fruit softening for the cultivars under study but no stable trend with titratable acidity (TA) was found. Based on the results 1-MCP may be a treatment for delaying ripening of European plum.
\end{abstract}

Keywords: 1-MCP, Ripening, Plum, Ethylene, Fruit quality, Respiration.

Fruit ripening is a sequence of biochemical processes, which change a physiologically mature but inedible fruit into an edible one. Plums are very perishable fruits with a short postharvest life compared to other climacteric temperate fruits such as apples and pears (Kader, 1992).Thus, the storage life can be extended if the biochemical processes are decreased. Generally, it is accepted that ethylene plays a key role in inducing ripening processes especially in climacteric fruits (Streif et al., 2010). Inhibition of ethylene biosynthesis or its action offers a good way to retard fruit ripening (Larrigaudiere et al., 2009). The exogenous application of products as 1-methylcyclopropene (1-MCP), aminoethoxyvinylglycine (AVG), polyamines (PAs), and nitric oxide (NO), have been found to be effective in delaying fruit ripening in many fruits (Khan \& Singh, 2008 and Khan et al., 2009).

The (1-MCP) has been found to be the most effective as ethylene inhibitor. It is a gas with molecular weight of 54, discovered by Edward Sisler and Sylvia 
Blankenship (Blankenship and Dole 2003). It is an inhibitor of ethylene action and has been widely used to improve shelf life and quality of plant products. The effect of 1-MCP on physiological behavior has been studied in many fruits. 1-MCP applications have been shown to reduce respiration and ethylene production rate in a number of climacteric fruits such as Japanese plum(Abdi et al., 1998 and Khan \& Singh, 2007), apple (Fan et al., 1999), apricot (Fan et al., 2000 and Dong et al., 2002), pears (Trinchero et al., 2004) and European plum (Valero et al., 2003).

The effect of 1-MCP application on postharvest quality has been studied in many fruits. Plum fruit softening is significantly retarded in 'Angeleno' Japanese plum by $1-\mathrm{MCP}$ treatment after storage at low temperature. Moreover, 1-MCP application could extend fruit shelf life and replace CA (Controlled atmosphere) storage for short or medium storage period (Menniti et al., 2006). Similar results have been obtained by other studies, which examined the effect of 1-MCP application on softening of plum fruit (Salvador et al., 2003, Valero et al., 2003, 2004 and Khan \& Singh, 2007, 2009). Suppression of the enzymes involved in fruit softening by the 1-MCP treatments has been proved in plum fruit (Menniti et al., 2004, Khan and Singh, 2007, 2009).

The influence of 1-MCP application on soluble solids contents (SSC) and total acidity (TA) has been studied in many fruits. There are some studies pointing out an increase in soluble solids content by applying 1-MCP in plums (Valero et al., 2004) and some apple cultivars such as 'Delicious' and 'Empire' (Watkins et al., 2000). But the 1-MCP treatments have no effect on SSC in some other fruits such as apricot (Dong et al., 2002), orange (Porat et al., 1999), some apple cultivars (DeEll et al., 2002) and banana (Jiang et al., 2004). On the other hand, the loss of TA has been delayed by using 1-MCP application in many fruits, plums (Valero et al., 2003, Salvador et al., 2003 and Khan \& Singh, 2007), pineapples (Selvarajah et al., 2001), peaches (Liu et al., 2005) and some apple cultivars (Fan et al., 1999). However, the 1-MCP application has no effect on TA in some other species such as apricot (Dong et al., 2002) and orange (Porat et al., 1999) and are inconstant with some other apple cultivars (Watkins et al., 2000).

The objective of this work was to study the effect of 1-MCP on ripening and quality attributes of the European plums 'Katinka' (early ripening) and 'Haganta' (late ripening) in cold storage and held at $20^{\circ} \mathrm{C}$ to ripe (shelf life).

\section{Material and Methods}

Fruit, 1-MCP treatment, and storage conditions

Fruits of the European plum (Prunus domestica L.), cultivars 'Katinka' and 'Haganta' were harvested at the experimental orchard of Technische Universität München at Freising-Weihnstephan during 2012 for 'Haganta' and 2013 for 'Katinka' and 'Haganta'. Fruits were manually harvested at commercial ripening stage and transported to the laboratory where they were sorted in order to remove mechanically damaged fruit and fruits without stems. Fruits were pre-cooled at $2^{\circ} \mathrm{C}$ for at least $12 \mathrm{~h}$ before treatments. SmartFresh ${ }^{\mathrm{TM}}$ Technology (1-MCP

Egypt. J. Hort. Vol. 42, No.1 (2015) 
0.14\%, Dow AgroSciences) was applied at Bayerisches Obstzentrum. The powder was weighed and warm water was added to obtain a dosage of $0.625 \mathrm{ppm} 1-\mathrm{MCP}$. Treatments were performed in hermetically sealed plastic boxes $\left(0,015 \mathrm{~m}^{3}\right)$. Duration of treatment was $24 \mathrm{~h}$ at $1{ }^{\circ} \mathrm{C}$. Control fruits were treated in the same way but without 1-MCP as described by Fan et al. (2002). Following treatment, fruits were packaged in plastic boxes $(5-7 \mathrm{~kg})$ and stored at $2{ }^{\circ} \mathrm{C}(80 \pm 5 \% \mathrm{RH})$ for 20 to 50 days. Fruit samples were removed from cold storage after 10-15 days intervals and allowed to ripen at $20{ }^{\circ} \mathrm{C}$ for 3-7 days.

\section{Ethylene production and Respiration Rate}

To study ethylene production rate of the plum fruits during ripening, three replicates fromeach of the cultivars for each analysis time were chosen, about $1 \mathrm{~kg}$ for each replicate. Each replicate was placed in a sealed $3 \mathrm{~L}$ glass jar for 2 hours at $20^{\circ} \mathrm{C}$. Ethylene production was calculated by ethylene concentration in the gas phase of the headspace of the jars (Wang et al., 2010). From the headspace of every jar $1 \mathrm{ml}$ gas was withdrawn by syringe over a rubber septum and injected into a Carlo Erba 4200 Gas chromatograph (Carlo Erba, Spa, Milano, Italy) equipped with aluminum column 80/100 mesh, and a Flame Ionization Detector (FID). The temperatures of injector, oven and detector were 175,100 and $120^{\circ} \mathrm{C}$, respectively. The gas flow was $235 \mathrm{ml} / \mathrm{min}$ for air, $20 \mathrm{ml} / \mathrm{min}$ for hydrogen and $30 \mathrm{ml} / \mathrm{min}$ for nitrogen (carrier gas). Measurements were repeated for three or four times for every replicate. Ethylene production rate was calculated as $\mathrm{ppm} / \mathrm{kg} / \mathrm{h}$.

Respiration rate was measured as a function of $\mathrm{CO}_{2}$ concentration by using OXYBABY®(WITTGAS Co. Ltd., Germany) a mobile hand held gas analyzer after calibration with standard gases (Wang et al., 2010). Three replicates of each cultivar, each treatment, and each sampling time were used. For each replicate, $1 \mathrm{~kg}$ of fruit was placed in a $3 \mathrm{~L}$ airtight glass jar contained air as initial gas atmosphere for $2 \mathrm{~h}$. The gas was sampled through an airtight septum, and repeated three times for each replicate. Respiration rates of plumfruits were calculated as $\mathrm{ml} / \mathrm{kg} / \mathrm{h} \mathrm{CO}_{2}$. Res piration rate measurements were carried out only on 'Katinka' cultivar in 2013.

\section{Fruit quality analysis}

Fruit samples were analyzed for soluble solids concentration (SSC) and titratable acidity (TA) before and after cold storage, as well as before and after shelf life for every batch/cultivar. Soluble solids content (SSC) and titratable acidity (TA) were assayed for each freshly prepared juice sample. The SSC was measured using a digital refractometer and TA was determined by titrating $5 \mathrm{~mL}$ of juice with $0.1 \mathrm{~N}$ $\mathrm{NaOH}$ to $\mathrm{pH} 8.2$ using an autotitrator according to an AOAC method (AOAC, 1980). The SSC/TA ratio was calculated as well. Plum fruit firmness was measured with a tool for the rapid non-destructive evaluation of firmness of soft fruit (FirmTech 2), which gently squeezes the fruits to specified force to determine the fruit firmness. For plum, FirmTech has a turntable with 12 oval shaped indentures to hold the fruits. The FirmTech was calibrated for force and fruit size by manufacturer's tools. Firmnes s was measured by $\mathrm{mg} / \mathrm{mm}$. Measurements were performed in 2013 for 'Katinka', 'Haroma' and 'Haganta'. Weight loss was determined for fruits at cold storage and after held on $20^{\circ} \mathrm{C}$ for ripening according to the following equation 


$$
\text { Weight loss } \%=\frac{\text { Initialweight }- \text { Weightsampling date }}{\text { Initial weight }} * 100
$$

The statistical analysis was carried out by SPSS (version 16). The collected data were subjected to ANOVA analysis. Mean comparisons were performed using the Least Significant Differences (LSD) and Duncan tests to compare means at 5\% probability level. The other processing of data, graphical display and standard deviation (SD) of the results were performed by Micros oft office excel (Pivotable).

\section{Results and Discussion}

\section{Ethylene production and respiration rate}

Postharvest application of 1-MCP significantly reduced ethylene production both in the early cultivar 'Katinka' (Fig. 1 A, B, C) and in the late cultivar 'Haganta' (Fig. 2 and 3). In general, ethylene production of untreated fruits was significantly higher (at least 1.5 fold) as compared to treated fruits. Moreover, the climacteric rise was delayed with a lower peak of ethylene in 'Katinka' treated fruits at $2^{\text {nd }}$ analyzing time (after 20 days in cold storage, Fig. 1C). The ethylene production rate was slightly higher in treated fruits at the $2^{\text {nd }}$ day at $20^{\circ} \mathrm{C}$ after 10 days cold storage (Fig. $1 \mathrm{~B}$ ). Ethylene was detected neither in treated nor in control fruits of 'Haganta' 2012 during the first three days of ripening at $20^{\circ} \mathrm{C}$ in the first batch (without cold storage, Fig. $2 \mathrm{~A}$ ) and at the $1^{\text {st }}$ day in the $2^{\text {nd }}$ batch (after 15 days in cold storage, Fig. 2B). Ethylene production rate reached the climacteric peak after 12,8 and 7 days at $20^{\circ} \mathrm{C}$ for 'Haganta' 2012 in the first batch (without cold storage), the $2^{\text {nd }}$ batch (after 15 days of cold storage) and last batch (after 30 days of cold storage), respectively (Fig. 2). The same trend as for 'Katinka' was found for 'Haganta' in the $2^{\text {nd }}$ seas on (2013, Fig. 3). Respiration rate $\left(\mathrm{CO}_{2} / \mathrm{kg} / \mathrm{h}\right)$ was noticeably higher in control fruits compared to 1-MCP treated fruits (Fig. $1 \mathrm{a}, \mathrm{b}$ and c). In the $1^{\text {st }}$ batch (without cold storage) of 'Katinka' fruits, $\mathrm{CO}_{2}$ level has two peaks at $2^{\text {nd }}$ and $4^{\text {th }}$ day at $20^{\circ} \mathrm{C}$. Moreover, $\mathrm{CO}_{2}$ reached a maximum in laterbatches earlierthan in the first ones: the respiration rate reached the peak at $3^{r d}$ and $4^{\text {th }}$ day for $3^{r d}$ and $1^{\text {st }}$ batches, respectively. In general, 'Katinka' and 'Haganta' fruits exhibited a climacteric-like behavior in ethylene production and respiration rate (Fig. 1, 2 and 3). Ethylene plays a key role as a plant hormone responsible for coordinating and initiating ripening events in climacteric fruit (Abdi et al., 1998, Bapat et al., 2010). It triggers the processes of ripening and senescence. Ethylene inhibitors can delay the ripening of climacteric fruit (Liu, et al., 2005). The application of 1-MCP in some of Japanese and European plum cultivars showed beneficial effects such as: reduction of ethylene production, respiration rate and losses of fruit weight. In addition, fruit quality could be maintained and then, storability and shelf life could be extended (Abdi et al., 1998, Salvador et al., 2003, Valero et al., 2003). The reduction of ethylene production during shelf life, following or not cold storage, of European plum may be due to 1-MCP interaction with ethylene receptors (Blankenship and Dole 2003). Other possible causes could be the suppression of the enzymes 1-aminocyclopropene-1-carboxylic acid synthase (ACS, EC 4.4.1.14) and 1-aminocyclopropene-1-carboxylic acid oxidase (ACO, EC

Egypt. J. Hort. Vol. 42, No.1 (2015) 
4.4.17.4), and of 1-aminocyclopropene-1-carboxcylic acid content (Khan and Singh, 2007, 2009). It seems that some new receptors are being regenerated since ethylene production slightly started increasing. However, 1-MCP significantly decreased respiration rate in 'Katinka' and 'Haganta' (Fig. 4-39). These results are in accordance with findings by Dong et al. (2002), Salvador et al., (2003) and Valero et al. (2003, 2004). 'Katinka' showed a biphasic pattern in respiration rate during ripening at room temperature in treated and untreated fruits. This behavior was reported in previous study on banana (Musa accuminata L. cv. Cavendish) and Japanese plum by Khan et al., (2009). On the other hand, they found that treating 'Tegan Blue' Japanese plum fruits with high MCP doses (2.0 ppm) prevented any respiratory raise. However, the effect of $\mathrm{MCP}$ on respiration rate was not as pronounced as that found on ethylene production rate.

\section{Fruit quality attributes}

The effect of 1-MCP on fruit quality is presented in Fig. 4 to 8 . The 1-MCP had significant effect on fruit soluble solids content (SSC) especially after shelf life. SSC increased during cold storage and after shelf life in treated 'Haganta' plum fruits in seasons 2012 (Fig. 4 A) and 2013 (Fig. 5 A) but it decreased markedly in untreated fruits. The same trend was found in 'Katinka' (Fig. 6 A) except in the last batch (after 15 days in cold storage) either before or after shelf life without remarkable differences. These results confirm that 1-MCP delayed ripening in 'Haganta' and 'Katinka' fruits (Valero et al., 2004, Khan \& Singh, 2007 and Khan et al., 2009). However, other reports pointed out that 1-MCP had no effect on SSC of Japanese plum, apricot (Dong et al., 2002, Salvador et al., 2003) and orange (Porat et al., 1999).

Regarding acidity (TA), it decreased after shelf life in both treatments, seasons and for cultivars 'Katinka' (Fig. 5 B) and 'Haganta' (Fig. 4B) except 'Haganta' at the $3^{\text {rd }}$ analyzing time in control treatment showing slightly increased TA values (Fig. 5 B). Applying 1-MCP treatment, there were no pronounced changes of TA. The 1-MCP treatment in 2012 season gave slightly higher TA at the beginning of cold storage of 'Haganta', while no marked effect was found in the same cultivar as well as in 'Katinka' in 2013. These results are in accordance with results obtained by Dong et al. (2002) on apricot and Porat et al. (1999) on orange. However, there are contradicting reports for some apple cultivars (Watkins et al., 2000). In other observations 1-MCP could delay the loss of TA in European plum (Valero et al., 2003), peaches (Liu et al., 2005) and in some apple cultivars (Fan et al., 1999). The ripening index (SSC/TA ratio) increased during shelf life at $20{ }^{\circ} \mathrm{C}$ in both treatments but it was higher in treated fruits in both seasons and for both cultivars (Fig. 4 C, 5 C, 6 C). Exceptions were 'Katinka' fruits in the last batch (15 days of cold storage +3 days shelf life at 20 ${ }^{\circ} \mathrm{C}$ ) and 'Haganta' fruits in the first batches in both seasons where SSC/TA ratio was higher in control than in treated fruits. Generally, SSC/TA decreased during the whole storage period in 'Haganta' but not 'Katinka', where the SSC/TA was increasing during the storage period. 


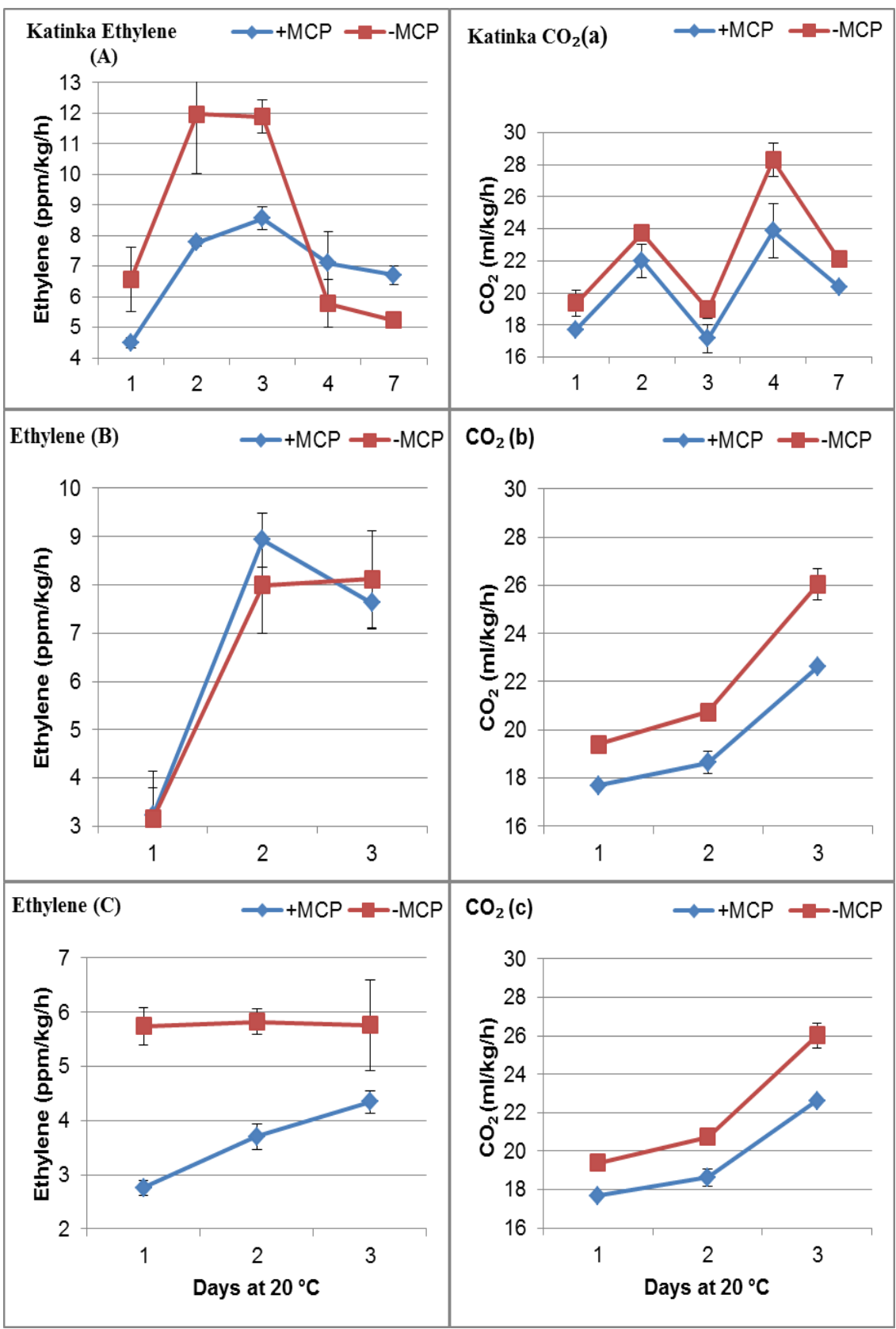

Fig.1. Effect of 1-MCP in ethylene production and respiration rate of 'Katinka' plum in 2013 during ripening at $20{ }^{\circ} \mathrm{C}$, after treating without cold storage (A), 10 days $(B)$ and 20 days stored in cold storage $(C)$. Values are mean of three replicates and vertical bars represent standard deviation (SD).

Egypt. J. Hort. Vol. 42, No.1 (2015) 

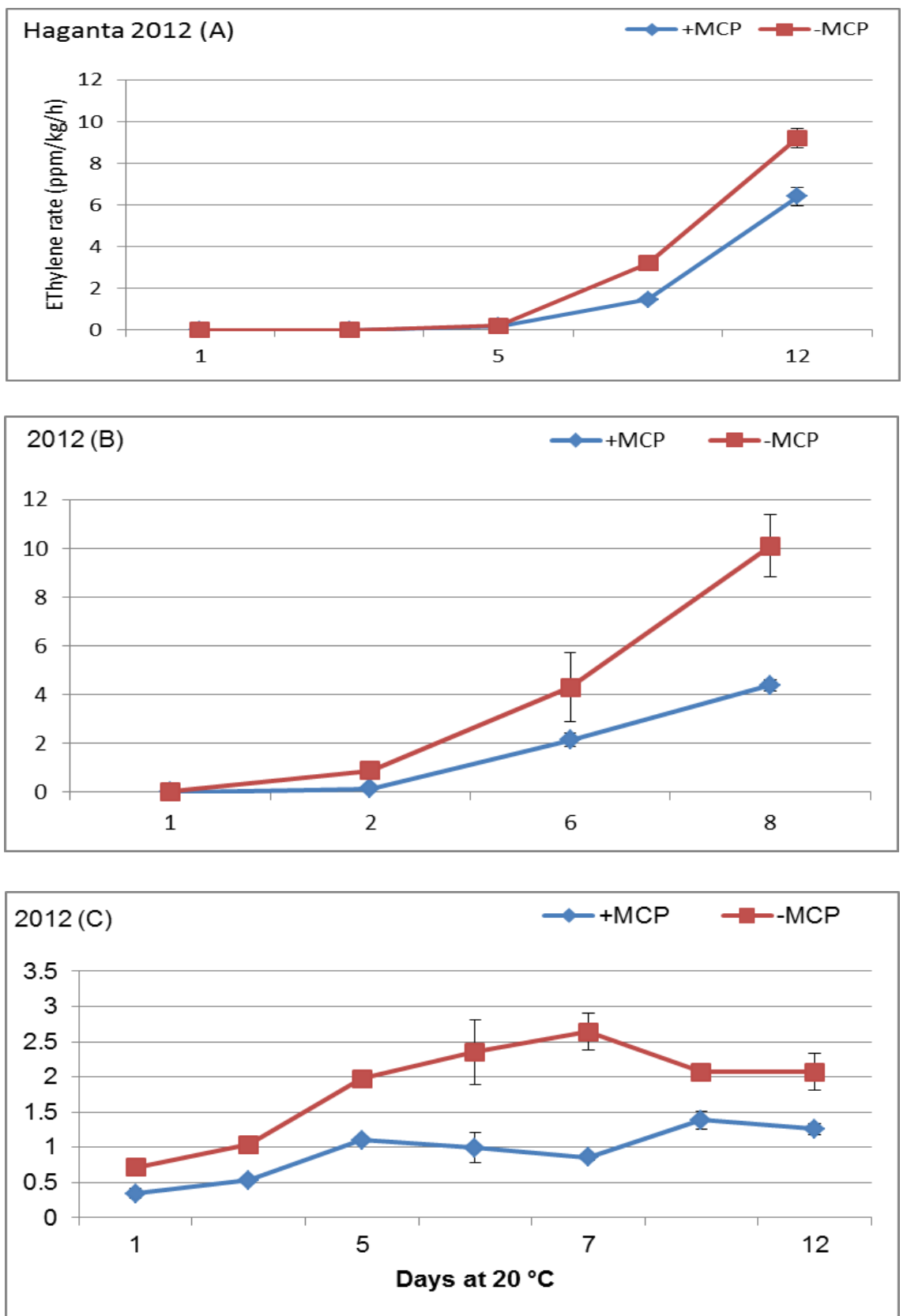

Fig. 2. Effect of 1-MCP on ethylene production rate of 'Haganta' plum in 2012 during shelf life at $20^{\circ} \mathrm{C}$, after treating without cold storage (A), 15 days (B) and 30 days stored in cold storage $(\mathrm{C})$. Values are means of three re plicates and vertical bars represent standard deviation (SD).

Egypt. J. Hort. Vol. 42, No.1 (2015) 


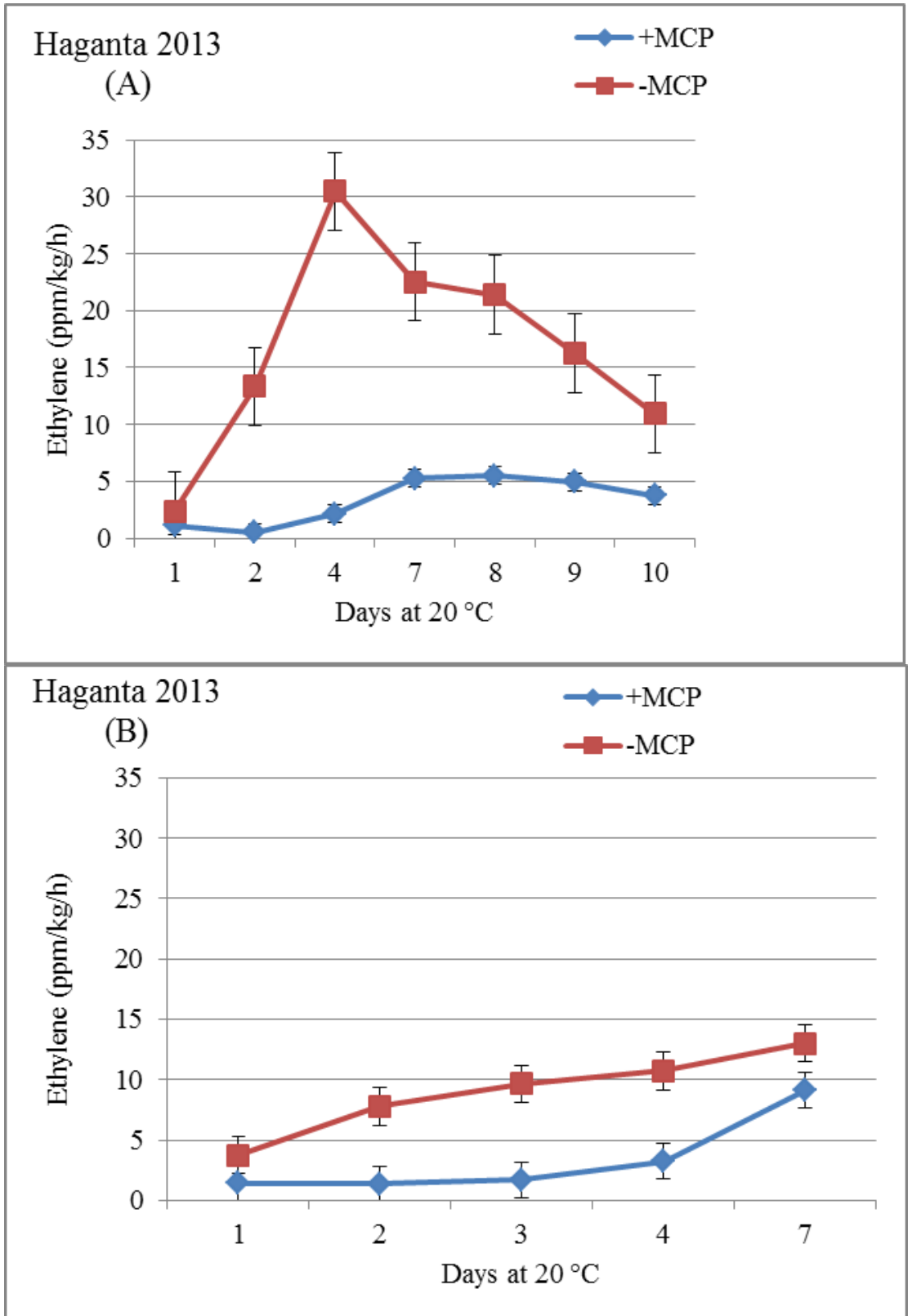

Fig. 3. Effect of 1-MCP on ethylene production rate of 'Haganta' plum in 2013 during shelf life at $20{ }^{\circ} \mathrm{C}$, after treating without cold storage (A) and 15 days stored in cold storage $(B)$. Values are means of three replicates and vertical bars represent standard deviation $(\mathrm{SD})$. 


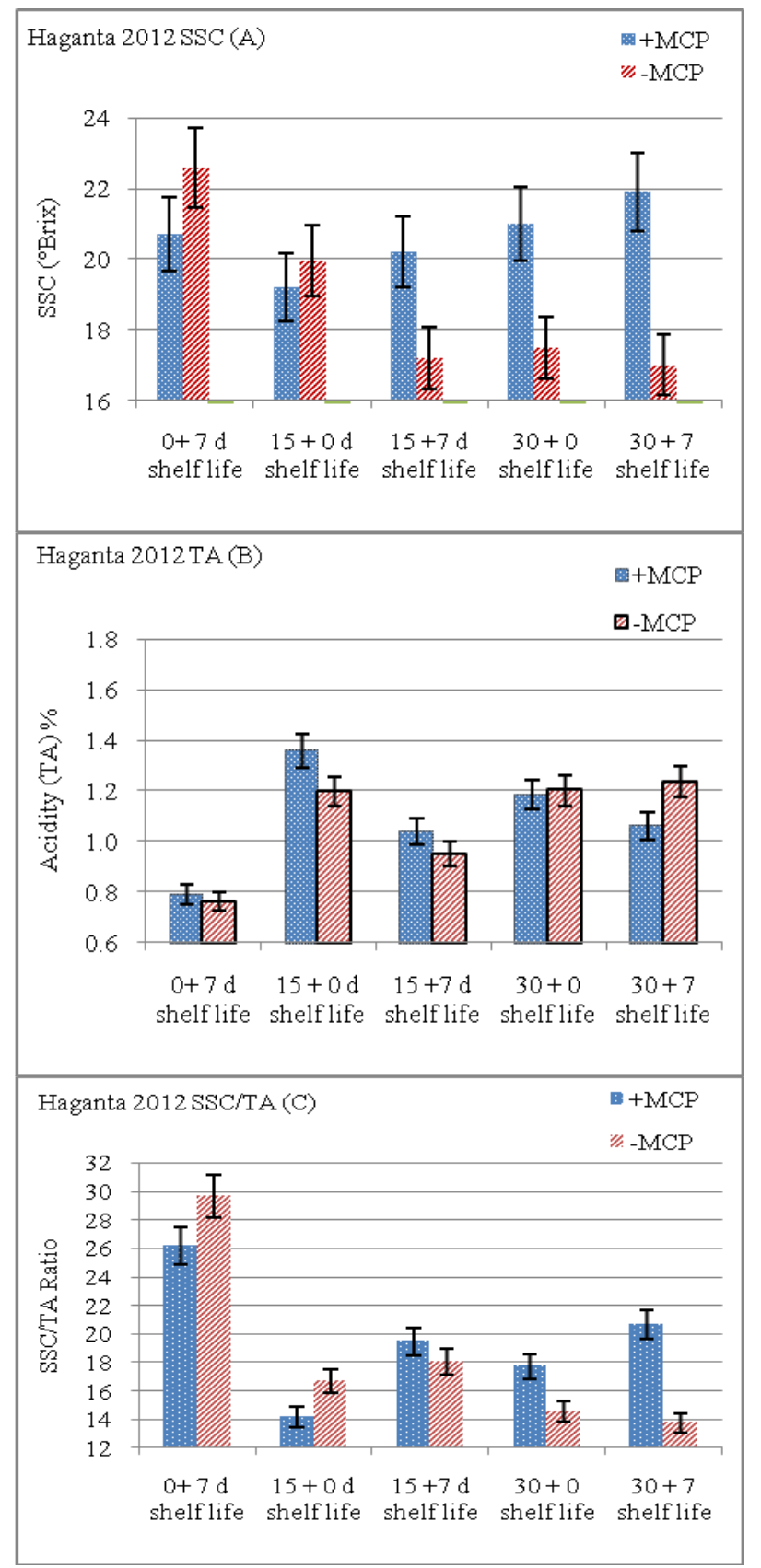

Fig. 4. Effect of 1-MCP on 'Haganta' plum fruit soluble solids content (S SC in ${ }^{\circ}$ Brix (A)), titratable acidity (TA in $\mathrm{g} / 100 \mathrm{ml}(\mathrm{B})$ ) and SSC/TA ratio (C) in 2012 season, after treatment $0,15,30$ days of cold storage followed by 0 and 7 days in shelf life $\left(\right.$ at $\left.20^{\circ} \mathrm{C}\right)$. 


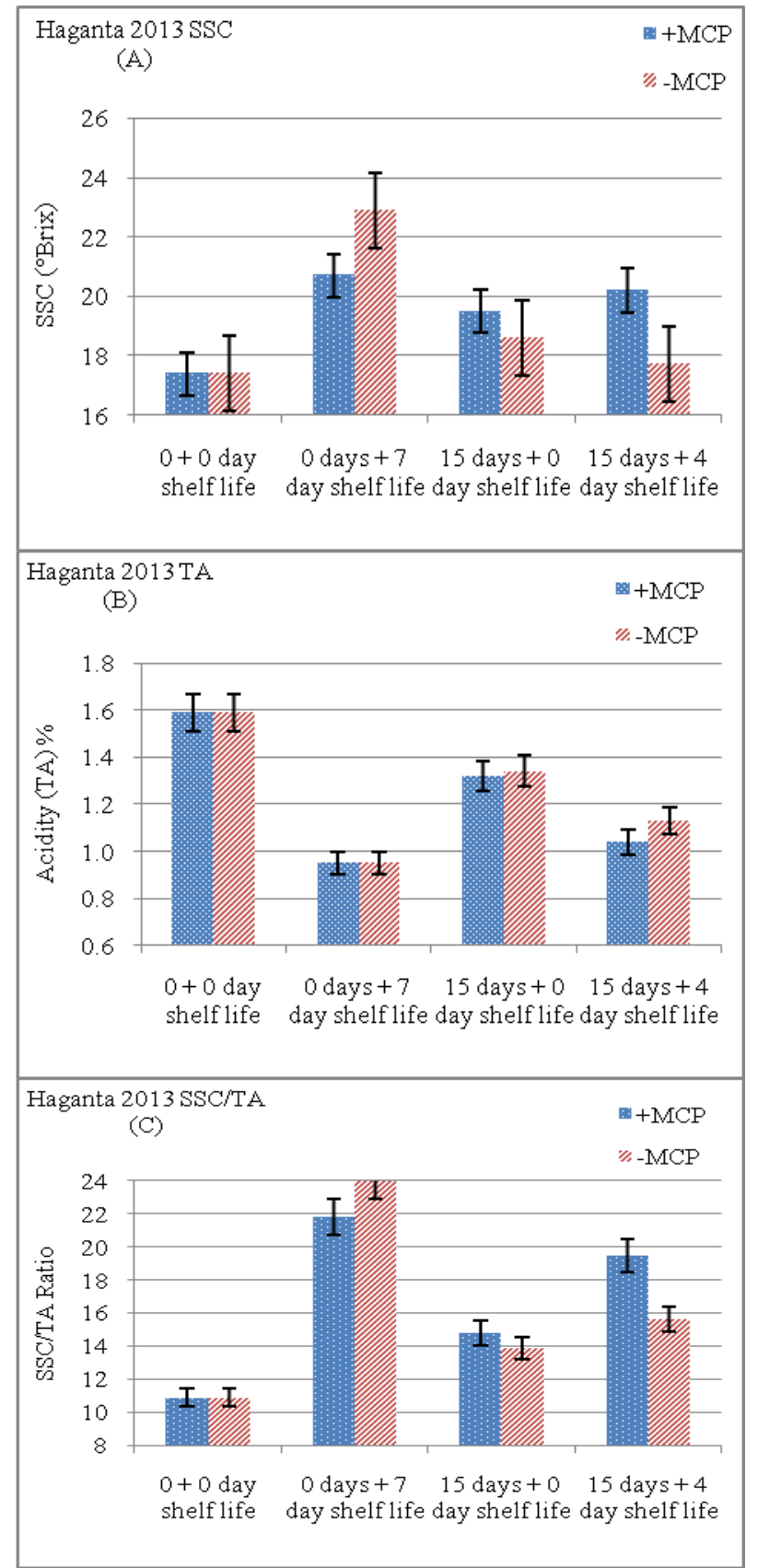

Fig. 5. Effect of 1-MCP on 'Haganta' plum fruit soluble solids content (S SC in ${ }^{\circ} B r i x$ (A)), titratable acidity (TA in $\mathrm{g} / 100 \mathrm{ml}(\mathrm{B})$ ) and SSC/TA ratio (C) in 2012 season, after treatment $0,15,30$ days of cold storage followed by 0 and 7 days in shelf life (at $\left.20^{\circ} \mathrm{C}\right)$.

Egypt. J. Hort. Vol. 42, No.1 (2015) 


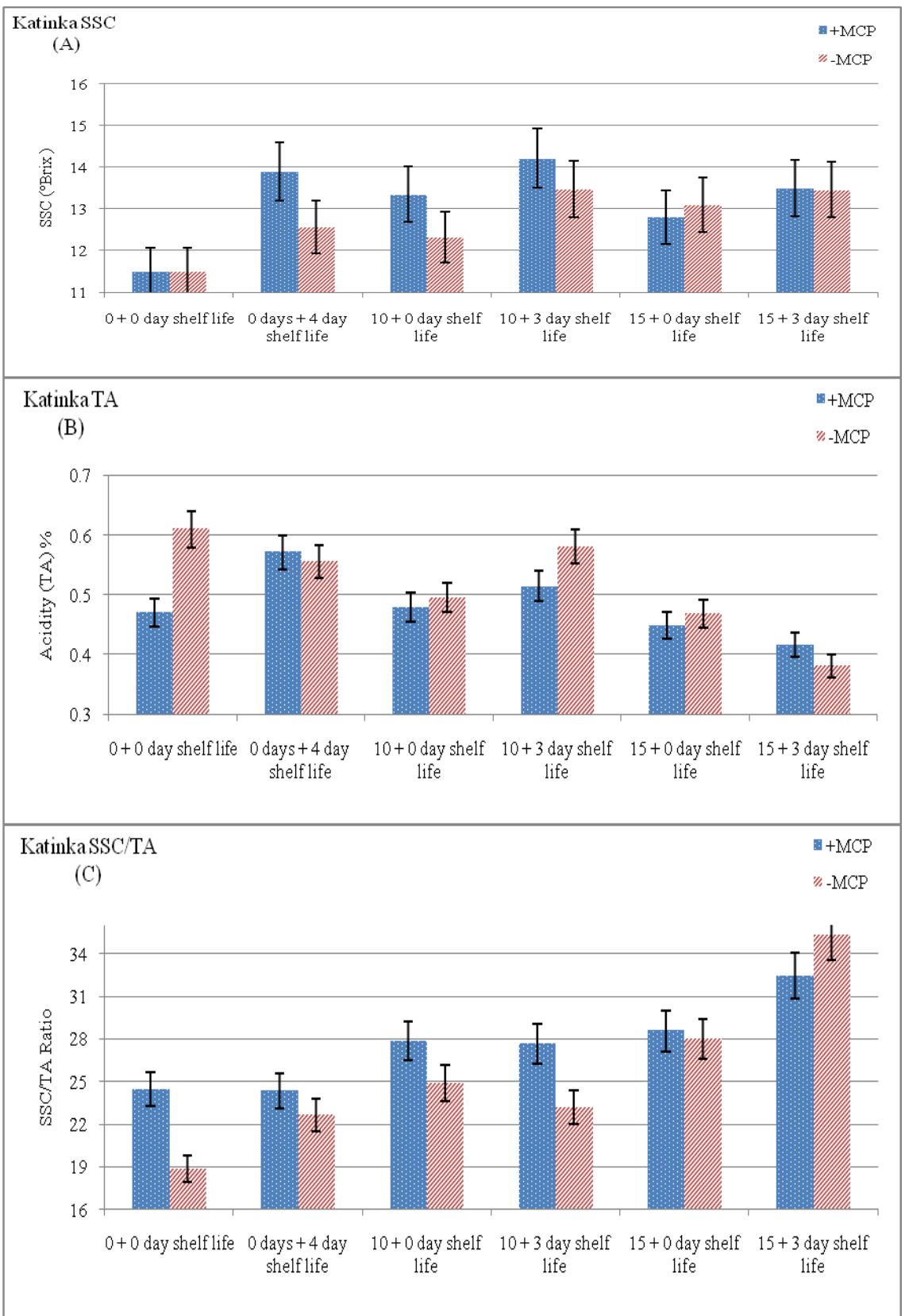

Fig. 6. Effect of 1-MCP on 'Katinka' plum fruit soluble solids content (S SC in ${ }^{\circ}$ Brix (A)), titratable acidity (TA in $\mathrm{g} / 100 \mathrm{ml}(\mathrm{B})$ ) and SSC/TA ratio (C), after treatment $0,10,15$ days of cold storage followed by 0 and 4 or 3 days in shelf life $\left(\right.$ at $\left.20{ }^{\circ} \mathrm{C}\right)$. 
Fruit weight loss

Fruit weight loss was slightly affected by the 1-MCP treatments. The untreated control exhibited higher weight loss than 1-MCP treatment during cold storage and followed shelf life at $20^{\circ} \mathrm{C}$. An exception was 'Haganta', 2nd batch ( 15 days of cold storage +5 days at room temperature), with a decreased weight loss percentage due to the 1-MCP treatment (Fig. 7). However, the effect of MCP on reducing weight loss was noticed by many authors, in plum (Valero et al., 2003) and avocado (Joeng et al., 2002). On the other hand, in apricot and orange no effect has been detected (Fan et al., 2000 and Porat et al., 1999). Loss of weight is one of the most important causes responsible for fruit quality deterioration.

\section{Fruit firmness}

The effect of 1-MCP application on fruit firmness before and after shelf life at $20{ }^{\circ} \mathrm{C}$ is shown in Fig 8. 1-MCP had marked effect on fruit firmness, since control plum exhibited less firmness than 1-MCP treated fruit. However, the differences were only significant in case of 'Haganta'. Generally, fruit firmness significantly decreased during shelf life in both treatments. The early ripening cultivar 'Katinka' has less firmness compared with the late ripening 'Haganta'. These results are in accordance with many authors for Japanese and European plum (Salvador et al., 2003, Valero et al., 2003, 2004, Khan and Singh, 2007, 2009).

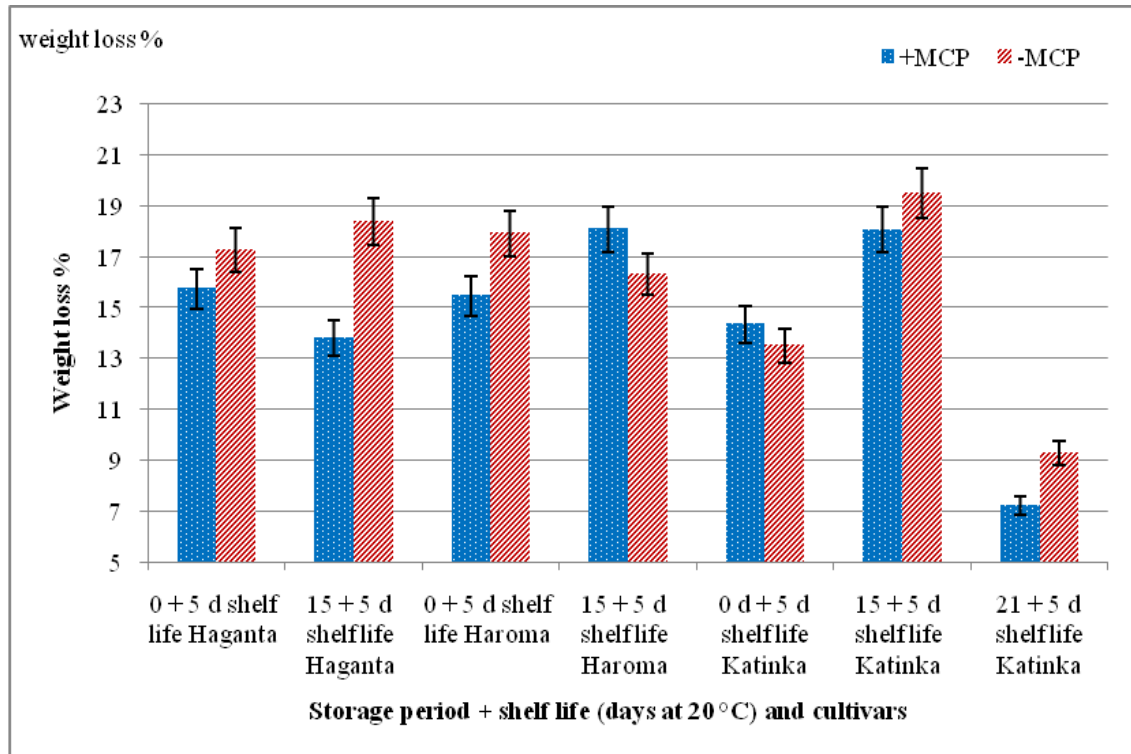

Fig. 7. Effect of 1-MCP on fruit weight loss of 'Katinka', 'Haganta' and 'Haroma' cultivars after treatment 0,15 and 21 days of cold storage followed by 5 days shelf life.

Egypt. J. Hort. Vol. 42, No.1 (2015) 


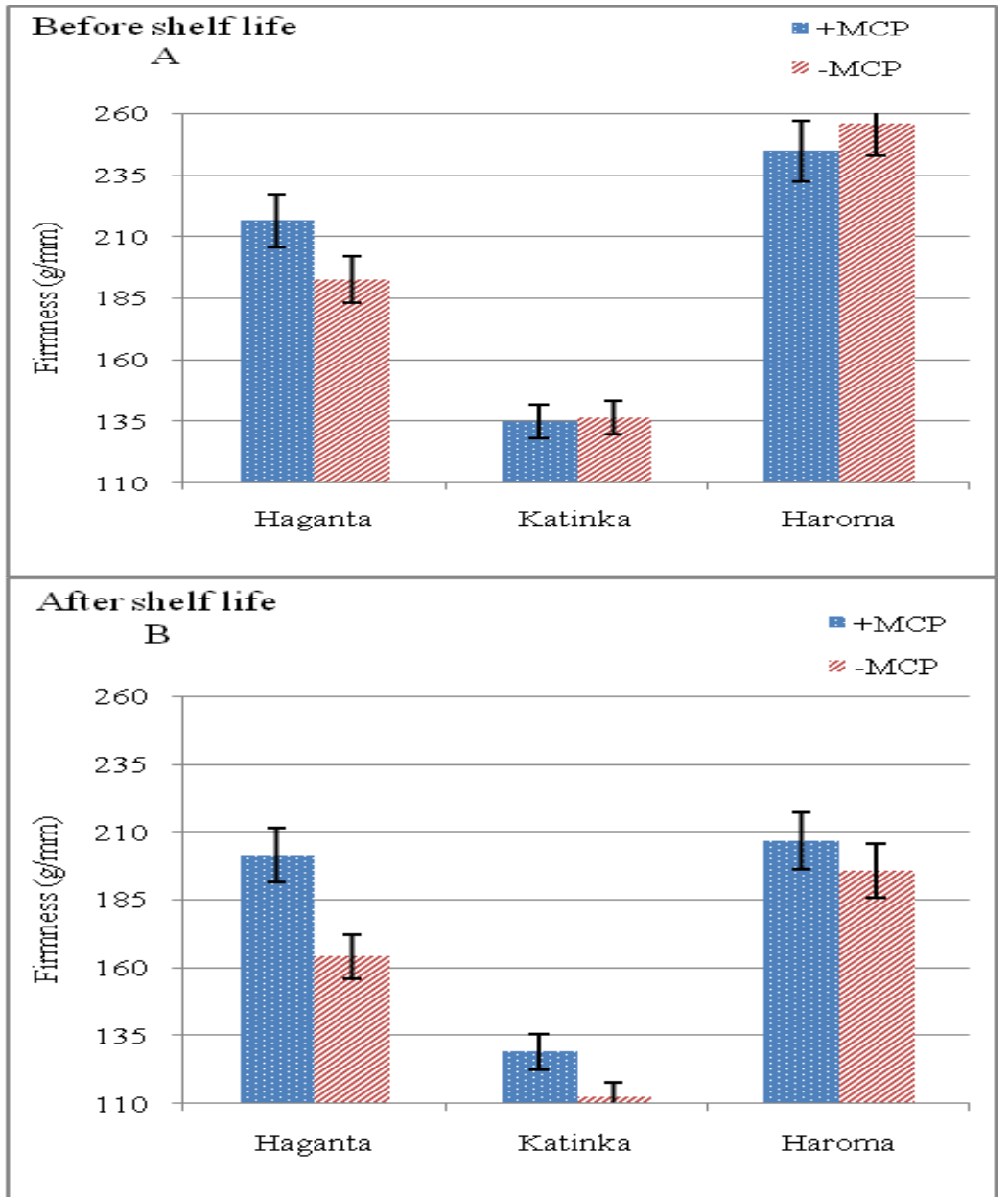

Fig. 8. Effect of 1-MCP on fruit firmness of 'Katinka', 'Haganta' and 'Haroma' cultivars before (A) and after (B) shelf life at $20{ }^{\circ} \mathrm{C}$ (5-7 days at room temperature).

\section{Conclusions}

The early ripening plum 'Katinka' has a rapid postharvest loss of fruit quality associated to a climacteric like increase in respiration and ethylene production compared to the late ripening cultivar 'Haganta'. The 1-MCP treatment reduced and delayed the increase of respiration and ethylene production during shelf life at $20{ }^{\circ} \mathrm{C}$ following harvest and cold storage. Soluble solids content (SSC) of 1-MCP treated fruits was low at the beginning of storage but was significantly higher SSC at the end of storage. Moreover, 1-MCP treatment significantly decreased weight loss and delayed fruit softening. Thus, the 1-MCP treatment has the potential to control ripening and extend shelf and storage life of European plum.

Egypt. J. Hort. Vol. 42, No.1 (2015) 


\section{References}

Abdi, N., McGlasson, W.B., Holford, P., Williams, M. and Mizrahi, Y. (1998) Responses of climacteric and suppressed-climacteric plums to treatment with propylene and 1 methylcyclopropene. Postharvest Biol. Technol., 14, 29-39.

Bapat, V.A., Trivedi, P.K., Ghosh, A., Sane, V.A., Ganapathi, T.R. and Nath, P. (2010) Ripening of fleshy fruit: Molecular insight and the role of ethylene. Biotechnol. $A d v ., 28,94-107$.

Blankenship, S.M. and Dole, J.M. (2003) 1-Methy lcy clopropene: a review. Postharvest Biol. Technol., 28, 1-25.

Dong, L., Lurie, S. and Zhou, H.W. (2002) Effect of 1-methylcyclopropene on ripening of 'Canino' apricots and 'Royal Zee' plums. Postharvest Biol Technol., 24, 135-45

DeEll Jr., Murr, D.P. Porteous, M.D., Rupasinghe, H.P.V. (2002) Influence of temperature and duration of 1-methylcyclopropene (1-MCP) treatment on apple quality. Postharvest Biol. Technol., 24, 349-353

Fan, X. T, and Mattheis, J.P. (1999) Impact of 1-methylcyclopropene and methyl jasmonate on apple volatile production. J. Agric. Food Chem., 47, 2847-53.

Fan, X.S. Blankenship, S . and J. Mattheis. (1999) 1-Methy lcy clopropene inhibits apple ripening. J. Amer. Soc. Hort. Sci., 124, 690-695.

Fan, X.T., Mattheis, J.P. and Roberts, R.G. (2000) Biosynthesis of phy toalexin in carrot root requires ethylene action. Physiol. Plant, 110, 450-454.

Fan, X., Argenta, L. and Mattheis, J.P. (2002) Interactive effects of 1-MCP and temperature on 'Elberta' peach quality. HortScience, 37, 134-138.

Jeong, J. and Huber, D.J. (2005) Suppression of avocado (Persea americana Mill.) fruit softening and changes in cell wall matrix polysaccharides and enzyme activities: differential responses to 1-MCP and delayed ethylene application. J. Am. Soc. Hort. Sci., 129, 752-759.

Jiang, W., Zhang, M., He, J. and Zhou, L. (2004) Regulation of 1-MCP-treated banana fruit quality by exogenous ethylene and temperature. Food Sci. Technol. Int., 10,15-20.

Khan, A. and Singh, Z. (2007) 1-MCP regulates ethy lene biosynthesis and fruit softening During ripening of 'Tegan Blue' plum. Postharvest Biol. Technol., 43 (3), pp. 298-306

Khan, A. and Singh, Z. (2009) 1-MCP application suppresses ethylene biosynthesis and Retards fruit softening during cold storage of 'Tegan Blue' Japanese plum. Plant Sci., 176 (4), 539-544.

Khan, A. and Singh, Z. (2008) 1-Methylcyclopropene Application and Modified Atmosphere Packaging Affect Ethylene Biosynthesis, Fruit Softening, and Quality of 'Tegan Blue' Jap anese Plum during Cold Storage. J. Amer. Soc. Hort. Sci., 133, 290-299. 
Khan, A.S ingh, Z. and S winny, E. (2009) Postharvest application of 1-Methy lcy clopropene modulates fruit ripening, storage life and quality of 'Tegan Blue' Japanese plum kept in ambient and cold storage. Int. J. Food Sci. Technol., 44 (6), 1272-1280.

Larrigaudière, C., Candan, A.P., Ubach, D. and Graell, J. (2009) Phy siological response of 'Larry Ann' plums to cold storage and 1-MCP treatment. Postharvest Biol. Technol., 51, 56-61.

Liu, H.X., Jiang, W.B., Zhou, L.G., Wang, B.G. and Luo, Y.B. (2005) The effects of 1methy lcy clopropene on peach fruit (Prunus persica L. cv. Jiubao) ripening and disease resistance. Int. J. Food Sci. Technol., 40, 1-17.

Manganaris, G.A., Vicente, A.R., Crisosto, C.H. and Labavitch, J.M. (2008) Cell wall modifications in chilling-injured plum fruit (Prunus salicina). Postharvest Biol. Technol., 48, 77-83.

Menniti, A.M., Gregori, R. and Donati, I. (2004) 1-methylcyclopropene retards postharvest softening of plums. Postharvest Biol. Technol., 31, 269-75.

Menniti, A.M., Donati, I. and Gregori, R. (2006) Responses of 1-MCP application in plums stored under air and controlled atmospheres. Postharvest Biol. Technol., 39: 243-246.

Porat, R., Weiss, B., Cohen, L., Daus, A., Goren, R. and Droby, S. (1999) Effects of ethylene and 1-methylcyclopropene on the postharvest qualities of 'Shamouti' oranges. Postharvest Biol. Technol., 15,155-163.

Salvador, A., Cuquerella, J. and Martinez-Javega, J.M. (2003) 1-MCP treatment prolongs postharvest life of 'Santa Rosa' plums. J. Food Sci., 68,1504-10.

Selvarajah, S., Bauchot, A.D. and John, P. (2001) Internal browning in cold-stored pineapples is suppressed by a postharvest application of 1- methylcyclopropene. Postharvest Biol. Technol., 23, 167-70.

Sisler, E.C., Serek, M. and Dupille, E. (1996) Comparison of cyclopropene, 1methylcy clopropene, and 3,3 dimethy lcy clopropene as ethylene antagonists in plants. Plant Growth Regul., 18, 169-74.

Streif, J., Kittemann, D., Neuwald, D.A., McCormick, R. and Xuan, H. (2010) Preand post-harvest management of fruit quality, ripening and senescence. Acta Hort. (ISHS) 877, 55-68.

Trinchero, G. Sozzi, G. Covatta, F. and Fraschina, A. (2004) Inhibition of ethylene action by 1-methylcyclopropene extends postharvest life of "Bartlett" pears. Postharvest Biol. Technol., 32,193-204.

Valero. D.. Martinez-Romero. D.. Valverde. .J. M.. Guillen. F. and Serrano. M. (2003) Quality improvement and extension of shelf life by 1-methyl cyclopropene in plum as affected by ripening stage at harvest. Inno. Food Sci. Emerging Technol., I4,339-48.

Valero, D., Martinez-Romero, D., Valverde, J.M., Guillen, F., Castillo, S. and Serrano. M. (2004) Could the 1-MCP treatment effectiveness in plum be affected by packaging? Postharvest Biol Technol., 34, 295-303.

Egypt. J. Hort. Vol. 42, No.1 (2015) 
Wang, R., Xuan, H. and Streif, J. (2010) Effect of 1-MCP on plum (Prunus domestica) ripening and quality during shelf-life at room temperature. Acta Hort. (ISHS) 877, 317-322

Watkins, C.B., Nock, J.F. and Whitaker, B.D. (2000) Responses of early, mid and late season apple cultivars to postharvest application of 1-methy lcy clopropene (1-MCP) under air and controlled atmosphere storage conditions. Postharvest Biol. Technol., 19, 17-32.

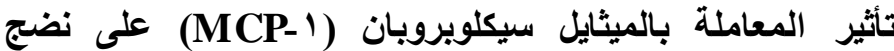 وجودة ثمار البرقوق الأوروبي (Prunus domestica L)}

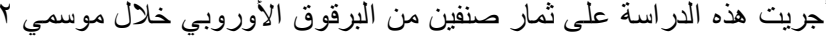

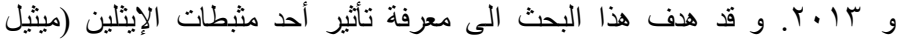

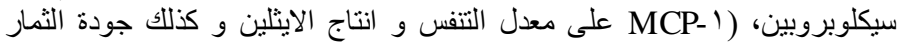

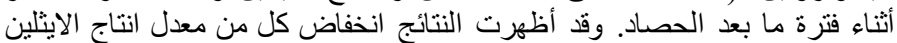

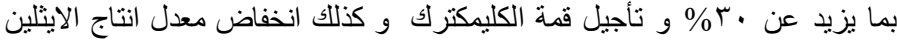

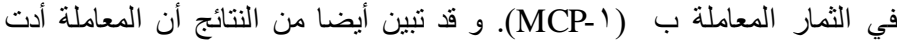

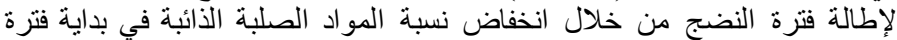

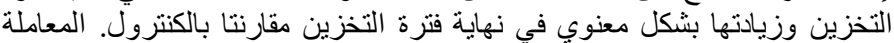

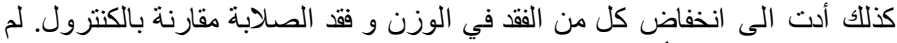

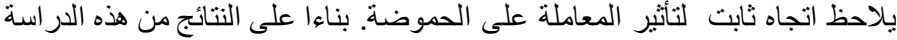

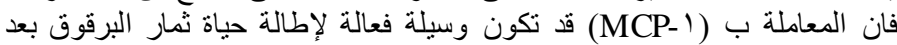

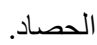

الكلمات المفتاحية : الاثيلين، النضج، جودة الثمار، التنف، (1) (MCP) . 